\title{
Interpretation and integration of "creating shared value" in Asia: implications for strategy research and practice
}

\author{
Rebecca Chunghee $\mathrm{Kim}^{1}$ (D) $\cdot$ Akira Saito $^{2}$ • V. Mohan Avvari ${ }^{3}$
}

Received: 5 March 2018 / Revised: 21 March 2019 / Accepted: 22 March 2019 / Published online: 15 April 2019 (c) The Author(s) 2020, corrected publication 2020

\begin{abstract}
"Creating shared value" (CSV) appears on contemporary business agendas. But despite empirical evidence concerning its popularity, serious questions about the logic of CSV are raised by scholars. This paper focuses on CSV in the Asian context. Using in-depth interviews with key informants from Japan, Korea, and India, we employ a strategy-as-practice approach and develop propositions related to CSV in Asia. We identify three characteristics of Asian business practices that shape CSV in Asia: a survival sense, a strong ethical stance, and business-in-society dynamics. Finally, we introduce a preliminary framework for Asian CSV along with suggestions for future research and practice.
\end{abstract}

Keywords Creating shared value $\cdot$ Corporate social responsibility $\cdot$ Business strategy $\cdot$ Asia $\cdot$ Japan $\cdot$ Korea $\cdot$ India

\section{Introduction}

Porter and Kramer (2011) propose "creating shared value" (CSV) as a new business strategy that insists on achievement of both social and economic value through competitive business models. Developing a value-generating business strategy may seem paradoxical, but it is timely and essential in this era of increasing demands from society that businesses play new roles. To respond to these pressures, many corporations are seeking to integrate social values into their business strategies, a phenomenon that is closely related to the emergence of CSV. However, much of the scholarly discussion around CSV remains ambiguous, and is arguably under-theorized. This

Rebecca Chunghee Kim

chkim1472@gmail.com; chunghee@apu.ac.jp

1 College of International Management \& Graduate School of Management, Ritsumeikan Asia Pacific University, 1-1 Jumonjibaru, Beppu City, Oita Prefecture 874-8577, Japan

2 Japan Society for Business Ethics Study (JABES), Tokyo, Japan

3 Nottingham University Business School, Semenyih, Malaysia 
study aims to address issues that have been raised about CSV by challenging Porter and Kramer's (2011) idea of strategy-focused CSV, through exploration of how the concept is currently interpreted and integrated in business practice and strategy in selected Asian countries.

We are cognizant that Asia is broad, and culturally and institutionally diverse, and that there are significant differences from one nation to the next (House et al. 2004; Kim and Moon 2015). In fact, the approach that different nations have taken to capitalism itself is divergent and complex in Asia; for example, highly coordinated capitalism is found in Japan, state-led capitalism in Korea, and hybrid market capitalism in India (Witt and Redding 2014). Therefore, it is challenging to undertake a comprehensive field study across the continent and reach a single conclusion concerning CSV in Asia. By focusing on Japan, Korea, and India, our aim is to initiate a uniquely Asian investigation of CSV with the goal of building a "preliminary Asian CSV framework" that can provide insights and serve as a foundation for further research on other Asian regions.

Our research began with a literature review that led to three research questions for developing a new conceptual and empirical understanding of CSV in Asia. These are: (1) Can CSV be embraced as a business strategy in Asia? (2) How can lucrative CSV be pursued, and is this possible in a business strategy sense in Asia? and (3) What kind of business-society relationships exist in Asia, and how can CSV contribute to those relationships in a strategic sense? Next we analyze the responses of managers and stakeholders to these questions, and identify some pieces of CSV logic that are found in Asia but are missing from or less prominent in CSV theory in general. This results in three propositions and a preliminary Asian CSV framework that highlights three latent factors of Asian CSV: a survival sense, a strong ethical stance, and business-in-society dynamics in a value creation strategy. We then discuss opportunities and challenges regarding CSV in strategy research and practice.

One of the most prominent elements of CSV in terms of its popularity among practitioners is the connection of strategy to social goals. The central premise of $\mathrm{CSV}$ is that the competitiveness of the organization and the betterment of communities surrounding it are mutually dependent (Porter and Kramer 2011). Hence, it is argued that CSV, through understanding and leveraging the connections between societal and economic progress, can unleash global growth and redefine capitalism (Crane et al. 2014; Pfitzer et al. 2013). CSV involves not only business strategy but also various phenomena occurring in society that go beyond business strategy; therefore strategic management of various stakeholders is inherent in CSV. To examine this comprehensive phenomenon, we conducted an extensive qualitative research study, gathering data through 77 face-to-face interviews with top managers, business practitioners, CSV/CSR professionals, related stakeholders, and academics in Asia during the period 2014-2017.

Despite the popularity of CSV in the business sector, questions about it have been raised by scholars, especially regarding conceptual vagueness, lack of factual grounding, and superficiality regarding the relationship between business and society. Crane et al. (2014) argue that the idea of CSV ignores difficult-to-resolve tensions between social and economic goals, due to a shallow grasp of the role of corporations in society. Other studies have criticized and cautioned against the very 
idea of CSV. Stuart Hart calls CSV "intellectual piracy" — an old idea in a new bottle with Porter's name on it, parading as "original" without acknowledging the true originators of the concept (Paramanand 2013). Dembek et al. (2016) call it more of a business buzzword than a theoretical concept, stating that it lacks ontology and epistemology. And Strand and Freeman (2015) call CSV no more than the "jointness of interests" tenet of stakeholder theory. These scholars call for urgent conceptual identification and empirical measurement of CSV.

In particular, Crane et al. (2014) strongly contend that CSV only seeks to "transform business thinking" while making no mention of the strategy models that might need transforming - merely proposing that CSR and capitalism need to be fixed. In this sense, consolidating CSV as a value creation strategy and developing an economic case for CSV is difficult without a robust strategic grounding of its concepts and a comprehensive understanding of market and context. To address these issues, we take a critical look at CSV in the Asian landscape, delving into CSV strategy and strategically relevant phenomena with which it is intertwined.

Given that CSV involves new strategies for firms in terms of resources and organization, we feel that Strategy as Practice $(\mathrm{SaP})$ is the lens needed to examine and understand the concepts of CSV. The SaP approach explores how managers or strategists work by focusing on micro-activities, rather than strategy at the organizational level. We are interested in the micro-activities related to CSV, and seek to understand how CSV fits into overall business strategy in Asia. Johnson et al. (2007) conceive of $\mathrm{SaP}$ as a clarifier of what people do in relation to strategy, and of how this is influenced by, and in turn influences, the organizational and institutional context. SaP also considers the "plurality" of actors in strategic decision-making, and includes not just senior management but managers at multiple levels as well as influential stakeholders (Jarzabkowski and Whittington 2008). Thus, research employing the $\mathrm{SaP}$ perspective requires a holistic approach that takes into account viewpoints of various key actors and distinct institutional contexts. In our examination of the CSV phenomena in Asia, we explore ideas and criticisms from business executives as well as actors from various stakeholder organizations in Japan, Korea, and India.

Many Asian nations are perceived as deviating from the Anglo-American economic model of shareholder control (Jackson and Moerke 2005; Witt and Redding 2014). Asian firms are expected to implement business strategies that consider stakeholders other than shareholders (Amann et al. 2012; Chikudate 2009; Lee et al. 2014; Tokoro 2007; Kannabiran 2009). The introduction of CSV is thus timely, and eagerly welcomed by corporations facing the dilemma of responding to this pressure (Kim 2018; Kim et al. 2016; Takashi 2015). This is evident from the different events related to shared value strategies that are held in various parts of Asia, such as the Porter Prize in Japan, Korea, and India, the Dong-A Business Forum in Korea, and Shared Value Summits in India. The interconnections between profit-making and Asian values are explored in the sustainability reporting and communications of many Asian corporations, including Toyota, Kirin, and Sony in Japan, Hyundai Motor Company, SK Group, and CJ Group in Korea, and TATA Group in India.

Many CSV-related managerial practices can be observed in Asia, but they attract limited theoretical support, and numerous critics. By exploring CSV as SaP in Asia, we hope to make two contributions. First, we propose three research questions that 
challenge the application of Porter and Kramer's (2011) ideas on CSV in the Asian context. We show that Porter and Kramer's writings have been misinterpreted, limited in use, and criticized to a large degree in Asia. This suggests that a "universal" approach towards CSV as a business strategy may be somewhat limited. By incorporating Asian voices and practices in our investigation, we hope to contribute to a more strongly-grounded understanding of CSV and its links with business conduct.

Second, and more substantively, we explore the CSV concept in Asia from an SaP perspective, with an eye to developing Asian-context specific propositions for CSV and a "Preliminary Asian CSV framework." These, we expect, will suggest directions for further empirical research and practice agendas. Our research shows that Asia has a unique take on the logic of CSV. The failure of firms operating in Asia to incorporate this perspective can lead to strategic problems and the distrust of society. Consequently, we close by suggesting implications for researchers and practitioners from the perspective of Strategy as Practice.

\section{Theoretical background}

\section{CSV and business strategy: Status in Asia}

"Shared value is defining a whole new set of best practices that all companies must embrace. It will also become an integral part of strategy."

(Porter and Kramer 2011, p. 15)

Porter and Kramer (2011) argue that CSV can be a useful tool for a higher form of capitalism, where profit and social purpose merge. CSV, unlike corporate social responsibility (CSR), is not made up of fringe activities, but lies at the center of business strategy. CSV postulates that social value creation should be embedded in the business's value chain. The fundamental idea of CSV stems from the need for an alternative view of business strategy to respond to the new rules and pressures of today's capitalism. Many scholars have proposed alternative views of business strategy that go beyond economic terms. Hart's (1995) theory of competitive advantage, for instance, focuses on the firm's relationship with the natural environment. Zenger (2016) argues that strategic thinking must move beyond competitive advantage to achieve sustained profitability.

Others, however, question whether a corporation's social value and performance need to be directly related to its business strategy. In reality, most CSR programs are not strategic (Dowling and Moran 2012; Rangan et al. 2015). Many companies have long practiced some form of social and environmental responsibility with the broad goal of contributing to the well-being of their communities and society, with these activities often loosely coupled to the organization's strategy. In this sense, business practitioners may well ask whether CSV, which emphasizes creating economic value by linking strategy with social values, is genuinely necessary, or even anything new, in the current global business environment. The greater problem, some argue, is the increasing pressure on companies to dress up socially responsible behavior as business strategy, such that every initiative is expected to deliver business results. This 
may be too much to ask of corporations, and could distract them from their primary goal of aligning their social and environmental activities with their business purpose and values (Rangan et al. 2015).

In Asia, "show me the money (profitability)" does not necessarily work well as the main rationale for a company's identity and strategy (McGinn and Zoltners 2015; Wu and Wokutch 2015). Instead, "show me moral/value stewardship and community contribution" is more critical for business survival in Asia (Chen et al. 2018; Jose 2016; Kim and Moon 2015). In this regard, Porter and Kramer's (2011) third key means of creating shared value, "enabling local cluster development," may be an especially effective strategy to follow in the Asian market, as it contributes to regional resilience (Lee et al. 2014).

Vogel's The Market for Virtue (2005) has a strong following in Asia, which suggests that the strategic use of CSR/CSV as a non-market dimension of strategy can be credible in Asia (Cheung et al. 2010; Dzever and Gupta 2012; Lee et al. 2014; Teng 2011). In Confucianism-influenced societies, strong emphasis is placed on social harmony and mutual respect, in life and in organizational systems (Chan et al. 2002; Jeong et al. 2017; Wong 2009). Building interpersonal trust is a key to survival and success, even though institutional trust is often weak (Choi et al. 2012; Wang and Juslin 2009; Witt and Redding 2014). In India, trust is closely related to "respect," and building trust is critical for a business in India to be viewed as responsible; this prompts many family-run Indian businesses to undertake activities that contribute to broader society (Sagar and Singla 2004). As the above implies, losing the trust of society by not engaging in responsible and ethical business practices is a big risk in the Asian environment and, hence, a major focus of a risk management strategy (Chung et al. 2019; Disparte 2016).

Given this, our first research question concerns the extent to which a strategyfocused sense of CSV is conceivable in Asian business dynamics. While it may sound logical and compelling, the CSV argument that social and economic value can be created simultaneously is questionable in view of the two dimensions of business "responsibility": creating economic value, and creating social value through ethical behavior that gains the trust and respect of society. Strategic thinking about value creation that goes beyond competitive advantage is called for (Zenger 2016). We expect that business practitioners in Asia may have views of and approaches to CSV as a business strategy that differ from those found in the West. Thus, our first research question is designed to explore this fundamental issue:

Research Question \#1: Can CSV be embraced as a business strategy in Asia?

\section{Is lucrative CSR the same as CSV? Status in Asia}

"The solution lies in the principle of shared value, which involves creating economic value in a way that also creates value for society by addressing its needs and challenges." (Porter and Kramer 2011, p. 4)

CSV logic starts with the shortcomings of CSR in terms of creating economic value. While CSR has emerged in recent decades as a hotly debated strategic 
management topic, not only for businesses but for a variety of stakeholders as well, it is arguably at odds with profit-making, and its outcomes are difficult to measure (Carroll et al. 2016). Corporations face a heterogeneous business landscape and display a wide variety of motivations for CSR. Scholars tend to fall into two camps: those who view CSR as an ethical model (e.g, Carroll and Bucholtz 2003) and those who see it as an economic model (e.g, Friedman 1970). Consequently, a universally accepted definition of CSR remains unestablished, and this, in turn, hampers practical implementation. To address these issues, Porter and Kramer (2011) propose CSV as a business strategy in which both economic and social issues are embedded in the value chain of the organization.

CSR today goes well beyond philanthropy. In the strategy literature there has a great deal of discussion about CSR from many perspectives, including its measurement (e.g., Carroll et al. 2016) and its legitimacy and new market potential (Hanlon and Fleming 2009). Although CSR has been criticized as corporate propaganda (Roberts 2003) and for limited integration with mainstream business (Alsop 2007), the path for placing CSR at the center of business strategy is evolving. Corporations are striving to adopt CSR as a critical business value and to better understand and improve the cost-benefit calculus of CSR activities (Paine 2003).

In the East Asian nations of Japan, Korea and China, where the influence of Confucianism is strongly felt, questions have long been raised about money-making business activities versus business morality and market ethics (Chan et al. 2002; Kim and Moon 2015; Wong 2009). Companies have always taken care to justify their profit-making in these Asian societies. Long before the appearance of Sandel's (2013) concept of "what money can't buy," markets have been unable to crowd out morals in Asia. Asians tend to feel strong antipathy toward making money from the costs and sacrifice of others, and are likely to associate blunt statements about money-making strategy with unethical behavior. In other words, Asia's assumptions about business profit and strategy are different in some ways from those of the West.

Debate on values and shared value systems is a common phenomenon in Asia (Barr 2000; Inoguchi and Newman 1997). Consequently, we may observe a flood of sustainability reports in Asia that stress “values." The annual reports of Japan's Mizuho Financial Group (2017) and Korea's SK Telecom (2014), for example, contain special "value creation" sections. Values are also closely related to many aspects of employer-employee relationships in Asia, such as group orientation, community interests, interdependence, and the social nature of human beings (Inoguchi and Newman 1997; Wu and Wokutch 2015; Valax 2012).

Value cannot easily be parsed into economic and social categories, however, (Hartman and Werhane 2013). "Economizing" value is tricky, especially in terms of reliable strategy metaphors. For instance, the economic view of "virtue" fuels faith in markets and propels their reach, but the metaphor is misleading, as virtue is not a commodity that is depleted with use (Sandel 2013). Thus, the CSV concepts of sharing and economizing value are subject to differing interpretations in Asia. To explore how CSV may be understood and practiced in an Asian business context, we pose our second research question: 
Research Question \#2: How can lucrative CSV be pursued, and is this possible in a business strategy sense in Asia?

\section{Business-society relationship as a trade-off: status in Asia}

"Business and society have been pitted against each other for too long."

(Porter and Kramer 2011, p. 4)

Porter and Kramer (2011) highlight what has long been an uneasy, and often hostile, relationship between business and society, and suggest that corporations should create shared value by reconceiving the interaction between social welfare and corporate performance. It is true that business has been subjected to considerable criticism (Carroll and Bucholtz 2003). Smith (1994) has called for businesses to be more responsible in their actions and contributions in order to build friendships with other parts of society. CSV encourages companies to discover, or create, overlap between economic and social progress using value principles. Scholars like Jones (1983) and Swanson (1999) discuss the need to integrate social issues into business strategy, and propose integrated frameworks for doing so. Nevertheless, these frameworks are oriented towards examining the social performance of businesses rather than understanding the relationship between business and society. We believe that the nature of the relationship of businesses and society must be examined more deeply and better understood.

CSV has been criticized for being based on a shallow understanding of the corporation's role in society (Crane et al. 2014). In Asia, few would agree that businesssociety relationships are necessarily bad. The interests of shareholders and those of the larger community are not always incompatible (Martin 2002; Tokoro 2007). Asian companies have always striven to build positive relationships with other parts of society. Smith (1994) argues that many Asian corporate citizens search for ways to align self-interest with the larger good of society. For example, although institutional adoption of CSR is a recent phenomenon in Japan (Suzuki et al. 2010), the traditional philosophy of Japanese management is to contribute to society by creating jobs and serve consumers by providing products and services that make their lives better. This creates positive relationships between employer and employee, and between company and other parts of society (Amann et al. 2012; Kim and Moon 2015; Saito 2008).

Asians naturally view "community" as a stakeholder, and often advocate "the right thing to do" with reference to long-standing religious and cultural practices and beliefs (Kim and Moon 2015). The problem in Asian business is not an antagonistic relationship between business and society, but rather overly intense or chronic links between some corporations and limited or especially powerful elements of society, such as government, family, industry, or even other Asian countries. This is reflected in the inclusive character of network-style integration in Asian capitalism, although this varies in form across the continent according to each nation's particular historical background, institutional context, and economic system (Katzenstein and Shiraishi 1997). 
Thus, the starting point of Porter and Kramer's argument-that "business and society have been pitted against each other for too long"- - does not accord well with widely held views of business and society in Asia, where it is taken for granted that businesses cannot be created, survive, or gain legitimacy without maintaining good relationships with communities and other parts of society. It is therefore valuable, in terms of evaluating CSV and its application in Asia, to examine Asian businesssociety relationships in light of the CSV concept and to drill down into questions of "What kind of?" and "How?" This leads to our third research question:

Research Question \#3: What kind of business-society relationships exist in Asia, and how can CSV contribute to those relationships in a strategic sense?

Figure 1 summarizes the research framework of this study. Specifically, it highlights how our three research questions were developed by considering three key tenets of CSV in the Asian context. While CSV is articulated by Porter and Kramer as a business strategy, in the Asian framework we break it into three issues: (i) how business executives and stakeholders view CSV as a business strategy; (ii) to what extent they see the lucrative or value-creation possibilities in CSV; and (iii) how, from a strategic perspective, CSV relationships or linkages between business and society in Asia differ from arm's-length relationships.

\section{Methods}

We employed the Strategy as Practice (SaP) perspective as our methodological lens for three reasons. First, instead of examining strategy as something that organizations have, we seek to elicit and understand people's concerns about strategy, and about what is actually being practiced (Johnson et al. 2007). We endeavor not to twist facts to develop and argue hypotheses, but rather seek to identify key questions and unveil issues related to CSV strategies and relevant phenomena. Second,

What Porter and Kramer said:

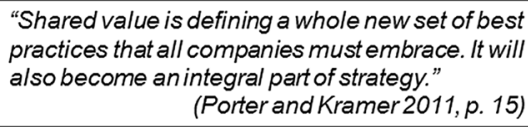

"Shared value is defining a whole new set of best practices that all companies must embrace. It will also become an integral part of strategy."

(Porter and Kramer2011, p. 15)

"The solution lies in the principle of shared value, which involves creating economic value." (Porter and Kramer 2011, p. 4)

"Business and society have been pitted against each other for too long."

(Porter and Kramer 2011, p. 4)
Issues on: Questions from Asia

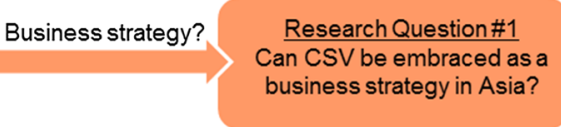

Research Question\#2 How can lucrative CSV be pursued, and is this possible in a business strategy sense in Asia?

\section{Research Question\#3}

Business-society relationships? What kind of business-society relationships exist in Asia, and how can CSV contribute to those relationships in a strategic sense?

Fig. 1 Research framework for this study 
as Vaara and Whittington (2012) state, the SaP approach offers an alternative to "performance"-oriented analysis and broadens the scope of strategy research to examine actual practices and phenomena. This suits our purpose, as our goal is to explore CSV practices and perceptions in an Asian setting. Third, we believe that this approach will allow us to explore CSV-related issues and dynamics in a way that reveals opportunities and challenges that arise in the application of CSV principles, and will thereby provide tangible insights for researchers and managers on how and to what extent CSV can be adopted as a business strategy. In our interviews we used open-ended questions concerning CSV in Asia, with the aim of gaining insights that generally inform strategy literature and practice (Bettis et al. 2015).

\section{Data collection}

We collected comprehensive qualitative data, including 77 in-depth interviews, during the period 2014-2017. We began by exploring the concept of CSV in Japan and Korea in order to develop a preliminary Asian framework, and added India at a later stage. The rationale for the three locations is as follows. In Japan and Korea, two countries that exemplify the rise of the East Asian economy, economic recession and repeated corporate misconduct and scandals over decades have led to intense discussion of the responsibilities of business (Amann et al. 2012; Choi and Nakano 2008; Chung et al. 2019). Moreover, in recent years CSV has become a hot topic of discussion in society and business circles in both nations (Kim et al. 2016; Takashi 2015).

Vibrant discussion of CSV is also found in India, although debates around CSV are led primarily by practitioners. As an example, the traditional concept of trusteeship, a Gandhian idea of how economic wealth should be governed, has been linked to the concept of shared value in India (Jose 2016). An Indian think tank named Institute for Competiveness also actively promotes CSV as a branch of Michael Porter's Institute for Strategy and Competitiveness. As India is one of Asia's most rapidly growing economies, and quite different culturally from Japan and Korea, we expected that adding it to our investigation would deepen and expand our research to include additional forms of value. It should also be noted that Porter has made highprofile visits to all three of these countries in order to disseminate and discuss CSV logic. For these reasons, we believe that valid and timely data on the emergence of CSV can be gathered in these countries.

Appendix 1 presents the details of our data gathering, which took place between 2014 and 2017. The primary corpus of data for our study comes from 77 face-toface interviews with business practitioners, CSV/CSR professionals, relevant stakeholders, and academics. 22 interviews were conducted in Japan, 13 in Korea, and 17 in India. In addition 21 interviews were conducted with managers and stakeholders of Japanese firms in Vietnam, and 4 were conducted with businesspersons in Malaysia and Singapore. For the interviews we selected key informants, executives, and decision-makers with expertise and experience in CSV-related issues. In the case of several key informants, two or three follow-up interviews were also conducted over the 4 years of the study to ensure that our information was kept up-to-date. 
The interviews were in-depth and semi-structured. All interviewees were assured that the information and opinions they shared with us would remain anonymous and confidential. We began by asking subjects about their prior understanding and views of the concept of CSV. We then followed clear interview guidelines, which were created based on the three research questions. The interviews were kept open-ended to allow individuals to talk freely about their understanding of and experience with $\mathrm{CSV}$, incorporating the context of the institutions to which they belonged. All discussion was kept within the overall themes of the study.

Our investigation is not a comparison of the three nations studied. Instead, we used the interview data to put together a broad picture of how CSV is understood and practiced in Asia. Rather than focusing on differences among the countries studied (Matten and Moon 2008; Witt and Redding 2012), we searched for commonalities and cross-linkages that could form the backbone of a "uniquely Asian" understanding and application of CSV. We view this as an important initial step that will provide a foundation for further investigation that extends this study to more complex systems and additional nations in Asia. For this reason, we call the model that is the outcome of this research a "preliminary" CSV framework for Asia.

\section{Data analysis process}

We performed three major steps for the data analysis. First, we identified key research questions related to CSV in an Asian context, based on a review of relevant literature. Second, we analyzed the resulting qualitative data, including 77 indepth interviews in Asian countries, by employing the Strategy-as-Practice (SaP) approach. Third, based on our findings, we generated testable propositions for our three research questions; this is similar to the approach taken by Il et al. (2016). Finally, as the outcome of our study, we developed a "preliminary Asian CSV Framework."

\section{Findings}

\section{CSV as a strategic sense versus survival sense}

We received a wide range of ideas in response to our first research question concerning whether CSV can be embraced as a business strategy in Asia. The most prominently expressed of these was the view that CSV lies at the root of traditional business in Asia. In other words, the foundation of CSV can be observed when one looks at business history. One business practitioner in Japan remarked:

"CSV is not just for good times, but should be practiced in bad times as well. After more than 400 years of management, it is clear to my company that CSV is shared value, and that it is especially important when the company faces difficulties. We should view CSV from the angle of business history. If we see it only in terms of outcomes and products, we cannot find genuine CSV."

(General Manager in CSR Team, Trading company, Japan, 2014) 
There is abundant evidence that many Japanese businesses introduce CSV in connection their company's founding philosophy. Kirin and ITO EN are examples of Japanese firms that explain CSV based on the philosophy of the founder or CEO. To shed more light on this phenomenon, we consulted a scholar in Tokyo who stated the following:

"In Japan, there were 'Omi merchants' in the Edo Period. They were the model for today's capitalism in Japan. They made and sold rice wine, and were notorious for making lots of money through usury. To prevent people from viewing their business practices as unethical - in other words, to survive as a rich person in Japan - Omi merchants adopted a traditional mission of always sharing with society, whether you are safe or at risk. It's all about risk management."

(Researcher in the field of Japanese traditional CSR philosophy, Japan,

Similarly, our interviews with Japanese businesspersons and stakeholders revealed a strong belief that for Japan, as an isolated island nation, a sense of connectivity and the practice of sharing are essential for survival. In Japan, business has traditionally been associated with the formation of community, and thus part of the foundation of society, as can be seen in the country's conventional "society-friendly" model of business (Fukukawa and Moon 2004). In this sense, it is not surprising that the Japanese business world tends to welcome the CSV concept (Takashi 2015), and that many respondents share the view that CSV is not a new concept as business strategy, but a long-established contributor to business longevity that has intimate links to national and community survival. As a recent example, we can point to how Japanese businesses were fully involved in the response to the 2011 Tohoku earthquake and tsunami, pooling resources to aid recovery efforts (Eweje and Sakaki 2015). For many Japanese companies, CSV is nothing other than putting their corporate philosophy and mission into practice, as sharing social and business values is a part of their survival DNA.

Respondents from Indian businesses and non-business organizations also echo the idea that CSR and CSV are connected not just with strategy but with survival. Many pointed out the connections between business activities and community or national development in areas such as hygiene, access to utilities like water or power, infrastructure, and women's empowerment. Interviews with familybusiness managers in India revealed that social development always occurs either where production facilities are located or in the home communities of business founders:

“.... Everything that you do in CSR/CSV is relevant to the stakeholders around you. So, in the case of my power plant, everything within a twentyfive kilometer radius of the plant is what I call my 'direct influence zone'."

(Director of Communications, Bioscience industry, India, 2017)

These findings show that, in addition to CSR-style activities like philanthropy or short-term charities, CSV-style business activities are practiced by companies not 
so much as strategy but as a means of creating mutual value that can help ensure business survival. For example, when companies provide health and education support to communities in which they operate, this leads to symbiotic benefits such as a better labor supply for businesses and higher employment for the community. Underlying these mutual benefits is the belief that if the society or community surrounding the company prospers, the business will also prosper. Corroborating this view, a senior vice-president of a leading MNC operating in India said:

"I acknowledge that community development activities are critical for the survival of businesses in India, as there is a strong 'feeling' that businesses can survive only if society or the community is prosperous. For example, our main business was going to be a dairy but there were no cows. How could our company get started? We began by encouraging and helping farmers to raise more cows. We engaged veterinarians to assist and support the farmers. We worked with medicine companies and negotiated prices that farmers could afford. In a nutshell, we worked with the community for mutual survival. That's the whole concept of what I would now call 'creating shared value'."

(Senior Vice President, Food \& drink industry, India, 2017)

Appendix 2 presents other sentiments from respondents that reflect the idea that $\mathrm{CSV}$ is necessary for survival. These observations echo the view that CSV goes beyond business strategy, that it involves a more holistic interaction between business and surrounding communities that facilitates the mutual survival of both society and business. We therefore argue:

Proposition \#1: CSV for Asian businesses is regarded as an imperative for survival rather than as an element of business strategy.

\section{Profit-focused CSV versus ethics-driven CSV}

A second prominent aspect of CSV as a business strategy in Asia that was revealed by our research is a widespread skepticism toward business in an ethical sense. This suggests that it may not be advisable, in Asia, to stress that CSV creates economic value for the firm. Porter and Kramer argue that CSV is neither philanthropy, nor CSR, nor even sustainability, but a new way for firms to achieve economic success. Many Western companies echo this idea by stressing the profit-generating value of their CSV activities. For instance, Pfitzer et al. (2013) cite Nestlé, Dow Chemical, and Vodafone as examples of firms that have created not just social but also economic benefits by creating shared value among businesses, communities, and government. Although companies take diverse paths toward combining social and business value, the argument is that economic gain is an achievable outcome of, and therefore a strong motivator for, adopting a CSV business strategy.

This argument may be less convincing in Asia, however, as a profit-driven approach toward CSV is likely to run into the issue of business ethics and trust (Chikudate 2009; Kim and Moon 2015; Lorenzo-Molo 2009). In the case of Korea, for example, many respondents expressed the idea that limits should be 
placed on profitable CSV; this violates the very premise of CSV as envisioned by Porter and Kramer. The comments of a Korean professor who is also CEO of a CSR consulting company give a hint of the Korean public's suspicions toward the motivations of big business and the pressure society puts on Korean firms to act in a more ethical and responsible manner:

“To be a 'good' company, the directions taken towards economic, legal, and philanthropic responsibility may be similar. However, to be a 'great' company, companies' responses to pressure to behave in a responsible way are (and will be) more critical. This can influence the direction of Asian CSV."

(Professor, former CEO of CSR consulting Co., Korea, 2017, translated

from Korean)

When CSV was first introduced to Korea, it received an enthusiastic welcome from the Korean business sector. Although there had been increased demand for the implementation of corporate strategies that take stakeholders' expectations into consideration (Lee et al. 2014), CSR could not serve as a sufficient response to this pressure as it has not been rigorously institutionalized in Korea. Moreover, discussion in Korea of CSR was tied to the theme of philanthropy, alongside the idea of "spending money" or "giving up profit" (Kim et al. 2016). The failure of CSR strategies led many Korean companies to have high hopes for and to quickly adopt the concept of CSV as a business strategy - not as the result of systematic evaluation, but as an ad hoc solution for overcoming the shortcomings of CSR (Choi et al. 2015).

However, the overall response from society towards these corporate endeavors has been skepticism. There is widespread suspicion towards companies' motivation for adopting CSV; many believe it is simply to improve business image as alternative communication strategy (Choi et al. 2015; Kim et al. 2016). The main reason for this is Korean society's chronic distrust of corporations:

"Why are Koreans so sensitive about the ethical performance of businessmen? Why are they so skeptical about CSV? I think that it is mainly due to people's distrust of business, in particular their distrust of corporate leaders. What they say about creating social value through business is absolutely right. But their behavior is uncontrolled and unethical, so we cannot perceive any sincerity from their message. Therefore, we don't care!"

(CSR Manager, Consumer goods Co. Korea, 2016, translated from Korean)

This distrust places more pressure on business to be "ethical" in Korea (Choi 2012; Kim et al. 2018). Even though Korean businesses have poured money into so-called CSR expenditures as a way of contributing to society-to the tune of US\$2.0 billion in 2008 and US\$2.6 billion in 2013 (The Federation of Korean Industries 2014) — society distrusts corporations because of their record of unethical behavior, which is closely coupled with the corrupt systems of institutions. One corporation's CSR budget was interpreted by the public and the courts as bribery, which resulted in the CEO being arrested (see Samsung case, Chun 2017). A low level of trust towards business and business leaders is found in 
Japan and India as well. In general, it can be said that Asian society pays greater attention to business leaders' ethical or unethical decision-making and behavior towards stakeholders and society than it does to how much money a company spends on CSR.

Appendix 3 presents quotations from our interviews concerning the issues of economic value from CSV and trust. These suggest that merely performing CSR-type "good deeds" is not enough to gain public trust; for a CSV-type business strategy to be effective, business operations must be ethical as well. We therefore argue:

Proposition \#2: Building "trust" in business and business leaders as ethical is a critical value-generating strategy in the Asian market.

\section{Tradeoff between business and society versus business in society}

Interestingly, there was little discussion in our interviews about an antagonistic relationship between society and business, which is contrary to Porter and Kramer's assertion (2011, p. 4) that "Business and society have been pitted against each other for too long." Instead, Asians appear to believe in the idea that building and operating a business is based on cooperation with and meeting the needs of the community or nation. This idea is expressed as sanpoyoshi (三方よl) and kyosei (共生) in Japan; sa-up-bo-guk (事業報國) in Korea; and seva (सेव: service) and neeti (नीत: conduct) in India.

Sanpoyoshi is literally "triple good"; it means "good business is that which satisfies sellers and buyers and contributes to society." Kyosei means "coexistence"; it refers to a spirit of cooperation, where individuals and organizations live and work together for the common good. Canon has used kyosei as the heart of its business credo (Kaku 1997). The traditional Korean philosophy of sa-up-bo-guk refers to the reason for business to exist: for the nation, so that the people can eat and survive. Many Korean conglomerates, including Samsung, Hyundai, and CJ Group, have traditionally used this philosophy as the foundation for their business's creation and existence. In India, it is evident that society is viewed as the foundation for a business's survival, although stakeholders say that businesses need to do more in order not to be perceived as exploitative. Nonetheless, stakeholders also state that Indian businesses have been a positive force in the development of society:

"Indian businesses have always had a philanthropic view of giving back to society in general, and particularly to the communities where they are located, as well as in the communities where the founders of the businesses came from. This is not embedded in their value chain, but is carried out through the companies' divisions or through their foundations."

(Senior Vice President, Fertilizer company, India, 2017)

Our research supports the idea that businesses in Asia see themselves as part of the society or community they operate in; they do not exist primarily to earn profit every quarter and maximize shareholder returns, but to serve the community and broader society for many generations to come. In this sense, corporations in Asia differ from their Western counterparts and from Western ideas about capitalism (Kim and Moon 
2015; Takashi 2015). Therefore, we do not believe that Crane et al.'s (2014) contention that CSV seeks to "redefine capitalism" and "transform business thinking" by addressing serious tensions between social and business goals applies very well in Asia. In Asia, as we have seen, engagement with society is already perceived as an integral part of business strategy, very much like what CSV aims for. The businesssociety relationship in Asia is not a tradeoff-one or the other-but more of a business-in-society phenomenon which Porter and Kramer overlook. Appendix 4 presents comments from our interviews regarding the role of business in society in the three Asian nations we studied. Even in the negative views expressed by interviewees from non-business organizations, it is evident that businesses and their activities are seen as in, not separate from, society. Therefore, we argue:

Proposition \#3: As businesses in Asia are viewed, and view themselves, as being in society, their voluntary efforts to play a positive role in society are a key to the success of value-generating strategies.

\section{Discussion and implications}

In contrast to the hypothesis-driven approach, this study focuses on identifying questions that challenge Porter and Kramer's (2011) ideas on CSV in terms of its potential as a business strategy in Asia. While the CSV concept resonates with some aspects of the Asian business environment, we identified three characteristics of Asian business that do not match up well with Porter and Kramer's ideas about CSV and some of their underlying assumptions: a survival sense, a strong ethical stance, and business-in-society dynamics. From these characteristics, we generated the three above-stated propositions concerning how CSV can be interpreted and applied in Asia. Assimilating these propositions into the overall results of our research, we developed and propose an integrated "preliminary Asian CSV framework" (Fig. 2) that shows how CSV in Asia differs from that envisioned by Porter and Kramer. Allow us to reiterate here that, because our study was limited to three Asian countries, this framework should not be regarded as a completed model for Asia but as a starting point for further theoretical and practical research regarding CSV in Asia.

\section{Theoretical contributions}

Theoretical concepts for understanding and evaluating the creation of social value are scarce (Crane et al. 2014; Kroeger and Weber 2015). Porter and Kramer's CSV has attracted attention from both scholars and business practitioners as a promising strategic approach by which firms can create both economic and social value. Yet it is unclear how "universal" the logic of Porter and Kramer's CSV concept is. It may be that, like other theories and business models before it, it is based on some assumptions that are valid in one environment, for example Western business, but less valid in another environment, for example business in Asia. Therefore, the study of CSV in an Asian setting is valuable as a means of evaluating and further 


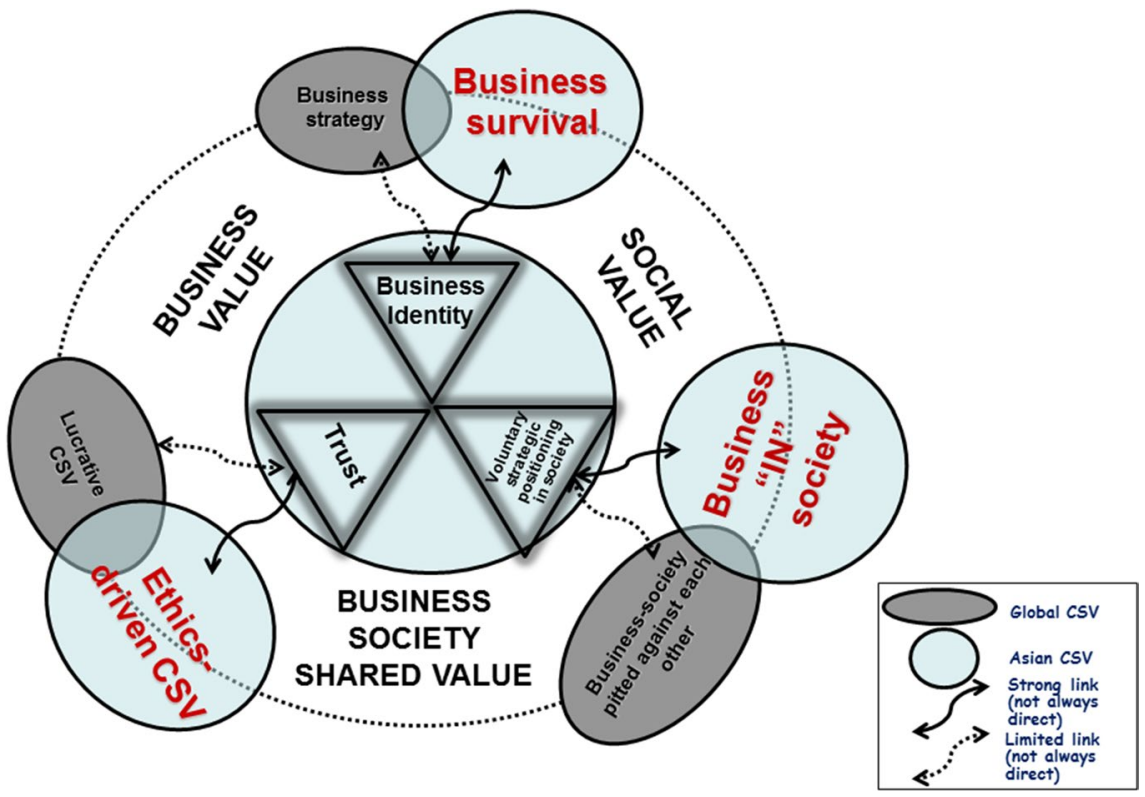

Fig. 2 Preliminary Asian CSV framework

developing the concept of CSV-either recognizing its limits or refining it so that it is more universally applicable. This is exactly what the present study seeks to do.

The primary theoretical contribution of this research is the development of a preliminary framework for understanding CSV in Asia. This framework, and the research that produced it, combine Porter and Kramer's concept of CSV with values and dynamics that are found in Asia. The framework highlights three characteristics of the Asian business environment that have important implications for the understanding and practice of CSV in Asia.

The first is that business organizations in Asia view CSV not so much as an optional tool of strategy but as a necessary means of survival. The second is that earning the trust of society, which is apt to view business and business leaders as unethical or interested only in their own economic gain, is the primary aim of shared value creation in Asia. The third is that businesses in Asia are viewed, by themselves and by society, as being a part of society, or in society. This contrasts with the starting point for Porter and Kramer's argument, which is that business and society are, or have long been, in an antagonistic relation, "pitted against each other." These three findings all shine a light on the CSV concept that may be helpful in further developing it so that it can be usefully applied in various different business environments. The findings also have implications for business managers operating in Asia; these are discussed below.

Although not strictly "theoretical," another contribution of this study is demonstration of the use of Strategy as Practice $(\mathrm{SaP})$ as a methodological approach for examining the practices, assumptions, values, and motivations that underlie business strategies and generating building blocks for theory development. It is the SaP 
approach, exemplified by extensive interviewing using open-ended questions, that allowed us to dig into contextual forces such as the importance of trust and normative social pressures on business to behave ethically and downplay, in their public statements, profit side CSV.

Although this has been mentioned above, it bears repeating that the present research study, being limited to three countries, is not intended to result in a "definitive" evaluation of CSV in Asia, but to illuminate aspects or dimensions of Asian CSV that can spur further research and theory development on this important subject.

\section{Managerial implications}

The implications of this study for managers of Asian firms or non-Asian firms operating in Asia derive from our three key findings regarding CSV in Asia: the view that CSV is key to survival of the firm; the importance of gaining and maintaining the trust of society; and the fact that firms are viewed not as outside and in opposition to society but as a part of and in society. These are all related. Because firms are viewed in Asia as being as a part of and in society, there are higher expectations that they operate in a way that earns and keeps society's trust. If firms were viewed as being apart from and in opposition to society - an underlying assumption of Porter and Kramer's CSV argument- then expectations of trustworthiness would not be so high. This is because people have a natural and strong need to be able to trust persons and organizations that are close to them; in contrast, it is natural (and perhaps wise) to be less trustful of persons and organizations that are viewed as being apart from or "pitted against" oneself. Finally, if firms' survival is at stake, it becomes even more necessary to gain public trust; good products and services may not be enough to ensure survival if a company is viewed as being unethical or socially irresponsible.

One implication of this is that business managers and executives that need to be acutely aware of the need to gain and hold the trust of society, and need to act in ways that ensure that their companies are genuinely ethical and responsible. A prominent example of failure to do this is the Korean conglomerates known as chaebols. Chaebols account for a substantial portion of the capitalization of firms listed on the Korea Exchange (KRX) stock market (Ryu et al. 2017) and they are credited with contributing significantly to Korea's speedy economic growth. As corporate social responsibility has gained attention, chaebols have loudly proclaimed that their business missions include creating social value and giving to society. But chaebols are also notorious for corruption and less-than-transparent management systems linked to their family ownership structure. For this reason, they are not trusted by society, and their CSR and CSV statements and activities are seen by the public as little more than window dressing: propaganda designed to cover up their mistakes and allow them to neglect public opinion. No matter what chaebols present in their business credos, mission statements, or CSV strategies, people do not believe them. This is not simply a matter of public relations; the problem is that they genuinely lack an ethical stance, and unethical practices by business, and by chaebols in particular, are no longer tolerated by the Korean public. As North (1990) has argued, the "rules of the game" have changed in Asian society. 
Such public distrust is especially problematic for large business organizations like chaebols. Ironically, studies suggest that when companies prominently publicize their ethical and social-contribution ambitions, they are more likely to attract critical stakeholder attention (Illia et al. 2013; Kim et al. 2013). And the more famous a corporation is, the greater the likelihood that its CSR initiatives will attract cynical critics (Cho and Hong 2009). The issue is exacerbated for chaebols due to a shortage of ethical business leadership behind the scenes, and the perceived misuse of CSR as "greenwashing" (Illia et al. 2013; Kim et al. 2018). If Korean chaebols fail to change their ways, their survival could be threatened, as questions are beginning to be raised as to whether their distinct ownership structure and corporate governance have truly been a positive influence on society and the economy (Chung et al. 2019; Moskalev and Park 2010).

A second practical implication of our findings, related to the above, is that businesses need to utilize effective ways to communicate with the public to build the trust necessary for survival. Many businesses remain naïve concerning the importance and challenges of responding to pressures from society to operate in an ethical way, and little attention has been given to exploring how corporations can most effectively communicate their social values to their various stakeholders, including investors, employers, and the general public (Chikudate 2009; Choi 2012; de los Reyes et al. 2017).

The need for companies to communicate more effectively with stakeholders to show that they are responsible and ethical coincides with technological advances that have drastically shifted the ways people interact with each other and the ways business interacts and communicates with society (Clark and Robert 2010). In today's internet-connected world, very little that businesses do goes unnoticed. Yet, while public surveillance of business has increased, businesses also have at their disposal powerful new means of communicating with society, such as corporate websites and SNS. Managers must use these effectively to convey to the world what their organizations stand for and what they do that creates value not just themselves but for society. In other words, they must fully use new communication tools to help build trust.

This is something that is a bit new for many Asian companies. A CSR manager of a leading Japanese trading company stated:

"Currently, we share all business information through our website and seek to actively communicate with global society. Traditionally, Asians tend to be reserved. You don't have to tell everybody what you are doing, you don't have to blow a trumpet. That was not Asian style. However, at this stage, as a corporation active globally, like ourselves, we need to be conscious that we need to be explicit and actively engaged in society in terms of communication and development. We cannot hide our mistakes. We should be able to convey our values to the outside people. Otherwise, we can't do business."

(CSR Team Manager, Trading industry, Japan, 2015)

In conclusion, we find high expectations of, as well as concerns about, CSV as a business strategy in Asia. We hope that this research will lead to further study and discussion among management scholars and practitioners regarding the practice of CSV in Asia and the resilience of the CSV concept in a broad variety of business environments. 
Funding The first author acknowledges the support of the Japan Society for the Promotion of Science (Grant no. 16K03840).

Open Access This article is licensed under a Creative Commons Attribution 4.0 International License, which permits use, sharing, adaptation, distribution and reproduction in any medium or format, as long as you give appropriate credit to the original author(s) and the source, provide a link to the Creative Commons licence, and indicate if changes were made. The images or other third party material in this article are included in the article's Creative Commons licence, unless indicated otherwise in a credit line to the material. If material is not included in the article's Creative Commons licence and your intended use is not permitted by statutory regulation or exceeds the permitted use, you will need to obtain permission directly from the copyright holder. To view a copy of this licence, visit http://creativecommons.org/licenses/by/4.0/.

\section{Appendix 1}

Selected data sources-In-depth interviews (Total: 77)

Interviews in Japan (Total: 22)

\begin{tabular}{|c|c|c|c|c|}
\hline No & Position & Department & Industry/sector & Date(s) of interview \\
\hline 1 & General Manager & $\begin{array}{l}\text { Environment \& CSR } \\
\text { Dept. }\end{array}$ & Trading & $\begin{array}{l}\text { (1) Aug } 82014 \\
\text { (2) Sep } 202014 \\
\text { (3) Feb } 172015\end{array}$ \\
\hline 2 & Manager & $\begin{array}{l}\text { Planning Team, Environ- } \\
\text { ment \& CSR }\end{array}$ & Trading & $\begin{array}{l}\text { (1) Aug } 82014 \\
\text { (2) Feb } 172015\end{array}$ \\
\hline 3 & $\begin{array}{l}\text { Assistant to General } \\
\text { Manager I }\end{array}$ & Logistics Dept. & Trading & Aug 82014 \\
\hline 4 & Senior Associate & Logistics & Trading & Aug 82014 \\
\hline 5 & Manager & Social Contribution Dept. & Trading & $\begin{array}{l}\text { Sep } 202014 \\
\text { (Sendai) }\end{array}$ \\
\hline $6(\mathrm{St})$ & $\begin{array}{l}\text { Former Country Chair- } \\
\text { man }\end{array}$ & Retired & Trading & Oct 32014 \\
\hline 7 & $\begin{array}{l}\text { Assistant General Man- } \\
\text { ager }\end{array}$ & $\begin{array}{l}\text { Environment \& CSR } \\
\text { Dept. }\end{array}$ & Trading & Feb 172015 \\
\hline 8 & $\begin{array}{l}\text { Assistant to General } \\
\text { Manager }\end{array}$ & Secretarial Dept. & Trading & Feb 172015 \\
\hline 9 & $\begin{array}{l}\text { Assistant to General } \\
\text { manager II }\end{array}$ & Logistics Dept. & Trading & Feb 172015 \\
\hline 10 & $\begin{array}{l}\text { Assistant General Man- } \\
\text { ager }\end{array}$ & $\begin{array}{l}\text { Environment \& CSR } \\
\text { Dept. }\end{array}$ & Trading & $\begin{array}{l}\text { 1) Feb } 172015 \\
\text { 2) Mar } 232015\end{array}$ \\
\hline $11(\mathrm{St})$ & Associate Professor & & University & Sep 52016 \\
\hline $12(\mathrm{St})$ & Professor & $\begin{array}{l}\text { Former President of } \\
\text { JABES }\end{array}$ & University & Sep 52016 \\
\hline $13(\mathrm{St})$ & Dean & Faculty of Commerce & University & Sep 62016 \\
\hline 14 & President & Corporation Institute & IT & Sep 72016 \\
\hline 15 & $\mathrm{CEO}$ & & IT & Nov 282016 \\
\hline $16(\mathrm{St})$ & Research Head & $\begin{array}{l}\text { Researcher of Business } \\
\text { Ethics Research Center }\end{array}$ & Research Institute & March 302017 \\
\hline $17(\mathrm{St})$ & Professor & Faculty of Economics & University & March 302017 \\
\hline
\end{tabular}




\begin{tabular}{|c|c|c|c|c|}
\hline No & Position & Department & Industry/sector & Date(s) of interview \\
\hline $18(\mathrm{St})$ & Doctor & $\begin{array}{l}\text { Graduate School of Pub- } \\
\text { lic Management }\end{array}$ & University & March 312017 \\
\hline 19 & Senior Manager & $\begin{array}{l}\text { CSV Strategy Depart- } \\
\text { ment }\end{array}$ & Beverages & Sept 52017 \\
\hline 20 & Deputy Director & Group CSV Strategy & Beverages & Sept 52017 \\
\hline 21 & Deputy General Manager & $\begin{array}{l}\text { CSV Strategy Depart- } \\
\text { ment }\end{array}$ & Beverages & Sept 52017 \\
\hline 22 & Manager & $\begin{array}{l}\text { CSV Strategy Depart- } \\
\text { ment }\end{array}$ & Beverages & Sept 52017 \\
\hline
\end{tabular}

Interviews in Korea (Total: 13)

\begin{tabular}{|c|c|c|c|c|}
\hline No & Position & Department & Industry/sector & Date(s) of interview \\
\hline 1 & President \& CEO & & Consulting & $\begin{array}{l}\text { (1) Sep } 22014 \\
\text { (2) Feb } 222016 \\
\text { (3) Mar } 202017\end{array}$ \\
\hline $2(\mathrm{St})$ & Professor of Management & Business School & University & $\begin{array}{l}\text { (1) Sep } 32014 \\
\text { (2) June } 12016 \\
\text { (3) Mar } 92017\end{array}$ \\
\hline 3 & Assistant Manager & CSR Team & Consumer Goods & Feb 192016 \\
\hline $4(\mathrm{St})$ & Director & & Government Institution & Feb 232016 \\
\hline 5 & Group CEO & & CSR Consulting & May 312016 \\
\hline $6(\mathrm{St})$ & $\begin{array}{l}\text { Vice President \& Secretary } \\
\text { General }\end{array}$ & & International NGO & June 22016 \\
\hline $7(\mathrm{St})$ & Chief/Senior Researcher & Research Center & International NGO & June 22016 \\
\hline 8 & CEO and the President & & CSR Consulting & $\begin{array}{l}\text { (1) Nov } 242016 \\
\text { (2) March } 82017\end{array}$ \\
\hline $9(\mathrm{St})$ & Reporter & Corporation Dept. & Newspaper & Nov 242016 \\
\hline $10(\mathrm{St})$ & Professor & Business School & University & $\begin{array}{l}\text { (1) June } 32016 \\
\text { (2) Nov } 252016\end{array}$ \\
\hline $11(\mathrm{St})$ & $\begin{array}{l}\text { Visiting professor \& Direc- } \\
\text { tor }\end{array}$ & Institute for NPO & University & March 62017 \\
\hline $12(\mathrm{St})$ & $\begin{array}{l}\text { Founder \& Executive } \\
\text { President }\end{array}$ & & NPO & March 72017 \\
\hline 13 & Partner of CSR & & Consulting & March 82017 \\
\hline
\end{tabular}

Interviews in India (Total: 17)

\begin{tabular}{lllll}
\hline No & Position & Department & Industry/sector & Date(s) of interview \\
\hline $1(\mathrm{St})$ & Professor & Business School & University & July 24 2017 \\
$2(\mathrm{St})$ & Dean & Business School & University & July 24 2017 \\
3 & Honorary Chairman & CSV think-tank & NPO & July 25 2017 \\
$4(\mathrm{St})$ & CEO & CSV think-tank & NPO & July 25 2017 \\
5 & Senior Vice President & Corporate Affairs Div. of & Food \& Drink & July 25 2017 \\
& \multicolumn{2}{c}{ South Asia Region } \\
\hline
\end{tabular}




\begin{tabular}{|c|c|c|c|c|}
\hline No & Position & Department & Industry/sector & Date(s) of interview \\
\hline$\overline{6}$ & Senior Vice President & $\begin{array}{l}\text { Advocacy and Stakeholder } \\
\text { Relations }\end{array}$ & PR Consulting & July 252017 \\
\hline 7 & Consultant & Sustainability Dept. & Consulting & July 252017 \\
\hline $8(\mathrm{St})$ & Head & $\begin{array}{l}\text { Strategic Partnerships, } \\
\text { Policy Impact and Public } \\
\text { Relations }\end{array}$ & International NGO & July 262017 \\
\hline $9(\mathrm{St})$ & Director & $\begin{array}{l}\text { Institute for Public Enter- } \\
\text { prises (Pes) }\end{array}$ & University & July 272017 \\
\hline $10(\mathrm{St})$ & Dean & Institute for PEs & University & July 272017 \\
\hline $11(\mathrm{St})$ & Head of CSR & Institute for PEs & University & July 272017 \\
\hline 12 & Director & Corporate Communications & Power & $\begin{array}{l}\text { July } 272017 \\
\text { (Telephone interview) }\end{array}$ \\
\hline 13 & Senior Vice President & $\begin{array}{l}\text { Legal and Company } \\
\text { Secretary }\end{array}$ & Fertilizer & July 272017 \\
\hline 14 & Managing Director & & IT & July 282017 \\
\hline 15 & Head of HR & HR Dept. & IT & July 282017 \\
\hline 16 & Assistant Professor & Management & University & July 282017 \\
\hline 17 & Director & $\begin{array}{l}\text { Corp Communication and } \\
\text { CSR }\end{array}$ & Life Sciences & July 292017 \\
\hline
\end{tabular}

Interviews with employees/stakeholders of Japanese firms in Vietnam (Total: 21)

\begin{tabular}{|c|c|c|c|c|}
\hline No & Title & Department & Industry/sector & Date(s) of interview \\
\hline 1 & General Manager & $\begin{array}{c}\text { Corporate Group and } \\
\text { Financial Division }\end{array}$ & Trading & March 242015 \\
\hline 2 & $\begin{array}{l}\text { Deputy General Man- } \\
\text { ager }\end{array}$ & $\begin{array}{l}\text { Corporate Group and } \\
\text { Financial Division }\end{array}$ & Trading & March 242015 \\
\hline 3 & General Director & & Trading & March 232015 \\
\hline 4 & & $\begin{array}{l}\text { Tenant Relations Divi- } \\
\text { sion }\end{array}$ & Trading & March 232015 \\
\hline 5 & & $\begin{array}{l}\text { Senior Staff, Tenant } \\
\text { Support Dept. }\end{array}$ & Trading & March 232015 \\
\hline 6 & General Director & & Technology & March 232015 \\
\hline 7 & Assistant Manager & HR \& GA Dept. & Technology & March 232015 \\
\hline 8 & Assistant Supervisor & HR \& GA Dept. & Technology & March 232015 \\
\hline 9 & $\begin{array}{l}\text { Financial Controller } \\
\text { Director }\end{array}$ & & IT & March 232015 \\
\hline $10(\mathrm{St})$ & Principal & Local kindergarten & Local Community & March 232015 \\
\hline $11(\mathrm{St})$ & Principal & Local kindergarten & Local Community & March 232015 \\
\hline 12 & $\begin{array}{l}\text { Deputy General Man- } \\
\text { ager }\end{array}$ & & Trading & March 242015 \\
\hline 13 & Tenant Supporter & $\begin{array}{l}\text { Tenant Relations Divi- } \\
\text { sion }\end{array}$ & Trading & March 242015 \\
\hline 14 & & $\begin{array}{l}\text { Tenant Relations Divi- } \\
\text { sion }\end{array}$ & Trading & March 242015 \\
\hline $15(\mathrm{St})$ & General Manager & Admin Division & Manufacturing & March 242015 \\
\hline
\end{tabular}




\begin{tabular}{lllll}
\hline No & Title & Department & Industry/sector & Date(s) of interview \\
\hline $16(\mathrm{St})$ & Deputy Supervisor & General Affairs Section & Manufacturing & March 24 2015 \\
$17-20(\mathrm{St})$ & $\begin{array}{l}\text { (1) Chairman of the } \\
\text { community }\end{array}$ & Local Kindergarten & Local Community & March 24 2015 \\
& $\begin{array}{l}\text { (2) Manager of finan- } \\
\text { cial dept. }\end{array}$ & & & \\
& $\begin{array}{l}\text { (3) Head of school } \\
\text { (4) Teacher }\end{array}$ & & & \\
$21(\mathrm{St})$ & Vice President & Community Center & Local Community & March 24 2015 \\
\hline
\end{tabular}

Additional Interview/Consultation in other region (Malaysia/Singapore) (Total: 4)

\begin{tabular}{lllll}
\hline No & Title & Department & Industry/sector & Date(s) of interview \\
\hline 1 & Group Chief (M) & Internal Audit & Communications & Oct 4 2017 \\
2 & Managing Director (M) & $\begin{array}{c}\text { Malaysia, Philippines, } \\
\text { Vietnam \& Emerging } \\
\text { Markets }\end{array}$ & ICT/MNC & Oct 3 2017 \\
3 & $\begin{array}{c}\text { Co-Founder and Execu- } \\
\text { tive Director (S) }\end{array}$ & Director (S) & ICT & Oct 3 2017 \\
4 & Sustainability & Construction & Nov 30 2017 \\
\hline
\end{tabular}

ONLY interviewees' position, department, meeting date can be disclosed (protecting confidentiality and anonymity)

St Stakeholder

\section{Appendix 2}

Responses to question Q\#1-Can CSV be embraced as a business strategy in Asia?

\begin{tabular}{|c|c|c|}
\hline Country & Quotations & Interview date/location \\
\hline \multirow[t]{2}{*}{ Japan } & $\begin{array}{l}\text { "CSV is not just for good times, but should be practiced in bad times } \\
\text { as well. After more than } 400 \text { years of management, it is clear to } \\
\text { my company that CSV is shared value, and that it is especially } \\
\text { important when the company faces difficulties. We should view } \\
\text { CSV from the angle of business history. If we see it only in terms of } \\
\text { outcomes and products, we cannot find genuine CSV." } \\
\text { (General Manager, CSR Team, Trading company, Japan) }\end{array}$ & $\begin{array}{l}\text { September } 2014 \\
\text { Tokyo, Japan }\end{array}$ \\
\hline & $\begin{array}{l}\text { "For Japan as a traditional island nation, a sense of sharing or con- } \\
\text { nectivity is natural for survival." } \\
\text { (University professor, Japan) }\end{array}$ & $\begin{array}{l}\text { September } 2016 \\
\text { Tokyo, Japan }\end{array}$ \\
\hline
\end{tabular}




\begin{tabular}{|c|c|c|}
\hline Country & Quotations & Interview date/location \\
\hline \multirow[t]{2}{*}{$\overline{\text { Korea }}$} & $\begin{array}{l}\text { "The main reason for strategy-focused CSV in Korea is that corpora- } \\
\text { tions are searching for justification and legitimacy for their CSR } \\
\text { or social contribution activities. There are a lot of questions about } \\
\text { CSR strategy in Korea, so we hear a lot of 'let's get to the real } \\
\text { meaning!”" } \\
\text { (Visiting Professor \& Director of NPO, Korea) }\end{array}$ & $\begin{array}{l}\text { March } 2017 \\
\text { Seoul, Korea }\end{array}$ \\
\hline & $\begin{array}{l}\text { "Leading companies in Korea like Samsung are now worrying about } \\
\text { their positioning in the market. This means that there is more and } \\
\text { more consciousness of risk among businesses. In this light, I see } \\
\text { CSR/CSV as a way to acquire 'social value' in the market - to get } \\
\text { social support." } \\
\text { (Newspaper reporter, Korea) }\end{array}$ & $\begin{array}{l}\text { February } 2016 \\
\text { Seoul, Korea }\end{array}$ \\
\hline \multirow[t]{2}{*}{ India } & $\begin{array}{l}\text { "CSR/CSV can be a great cushion for business survival in times of } \\
\text { crisis." } \\
\text { (Director, Bioscience company, India) }\end{array}$ & $\begin{array}{l}\text { July } 2017 \\
\text { Hyderabad, India }\end{array}$ \\
\hline & $\begin{array}{l}\text { “...there are a few large, more advanced business organizations- } \\
\text { like TATA, ITC, some MNCs, unique organizations like AMUL, } \\
\text { public-sector organizations like GNFC (a fertilizer company)—-that } \\
\text { understand the 'strategic sense' of CSV, although they don't use the } \\
\text { term CSV. They could be the input for development of an Indian/ } \\
\text { Asian model of CSV.” } \\
\text { (Head of global NGO and MNC Vice-president, India) }\end{array}$ & $\begin{array}{l}\text { July } 2017 \\
\text { New Delhi, India }\end{array}$ \\
\hline
\end{tabular}

\section{Appendix 3}

Responses to question Q\#2-How can lucrative CSV be pursued, and is this possible in in a business strategy sense in Asia?

\begin{tabular}{lll}
\hline Country & Quotations & Interview date/location \\
\hline Japan & "Through this Overseas Industrial Park business, we can contribute to & March 2015 \\
& $\begin{array}{l}\text { Vietnamese society. But, the more important thing is: we can have } \\
\text { a good relationship with the Vietnamese community because of our } \\
\text { business. Beyond the economic value, the core of our relationship }\end{array}$ & \\
is TRUST." & Hanoi, Vietnam \\
& $\begin{array}{l}\text { (General Manager, Japanese trading co. in Vietnam) } \\
\text { "If a company openly says that they are doing CSR/CSV to create } \\
\text { profit/benefit, we will not trust them. Japanese may think that the } \\
\text { company is unethical and arrogant, so we do not trust them." } \\
\text { (Local government official, Japan) }\end{array}$ & Beppu, Japan \\
\hline
\end{tabular}




\begin{tabular}{|c|c|c|}
\hline Country & Quotations & Interview date/location \\
\hline \multirow[t]{2}{*}{ Korea } & $\begin{array}{l}\text { "To be a 'good' company, the directions taken towards economic, } \\
\text { legal, and philanthropic responsibility may be similar. However, to } \\
\text { be a 'great' company, companies' responses to pressure to behave } \\
\text { in a responsible way are (and will) be more critical. This can influ- } \\
\text { ence the direction of Asian CSV." } \\
\text { (Professor, former CEO of CSR consulting co., Korea) }\end{array}$ & $\begin{array}{l}\text { March } 2017 \\
\text { Seoul, Korea }\end{array}$ \\
\hline & $\begin{array}{l}\text { "Why are Koreans so sensitive about the ethical performance of } \\
\text { businessmen? Why are they so skeptical about CSV? I think that } \\
\text { it is mainly due to people's distrust of business; in particular their } \\
\text { distrust of corporate leaders. What they say about creating social } \\
\text { value through business is absolutely right. But their behavior is } \\
\text { uncontrolled and unethical, so we cannot perceive any sincerity } \\
\text { from their message. Therefore, we don't care!" } \\
\text { (Manager, CSR Team, Consumer goods co. Korea) }\end{array}$ & $\begin{array}{l}\text { February } 2016 \\
\text { Seoul, Korea }\end{array}$ \\
\hline India & $\begin{array}{l}\text { "Creating social value is not a small task. We do not worry about the } \\
\text { short-term profit side of CSR/CSV. Rather, we connect it with the } \\
\text { spiritual side of our business and organization." } \\
\text { (Managing Director, MNC, India) }\end{array}$ & $\begin{array}{l}\text { July } 2017 \\
\text { Hyderabad, India }\end{array}$ \\
\hline
\end{tabular}

\section{Appendix 4}

Responses to question Q\#3-What kind of business-society relationships exist in Asia, and how can CSV contribute to those relationships in a strategic sense?

\begin{tabular}{|c|c|c|}
\hline Country & Quotations & Interview date/location \\
\hline Japan & $\begin{array}{l}\text { "Now Japan has social problems-such as noncommunicable dis- } \\
\text { eases, rising health care costs, an ageing society, the disintegration } \\
\text { of bonds between people, and economic disparity-that are becom- } \\
\text { ing more and more serious. As a responsible alcohol producer, } \\
\text { we are working, first and foremost, to help solve alcohol-related } \\
\text { problems." } \\
\text { (Senior Manager, Group CSV Strategy, Beverage co.) }\end{array}$ & $\begin{array}{l}\text { July } 2017 \\
\text { Tokyo, Japan }\end{array}$ \\
\hline \multirow[t]{2}{*}{ Korea } & $\begin{array}{l}\text { "In the digital era, business information and performance should be } \\
\text { open to society. Along with bad news, business's creation of social } \\
\text { value can be naturally disseminated and sensitively appraised by } \\
\text { society through SNS." } \\
\text { (President and CEO, CSR Consulting co., Korea) }\end{array}$ & $\begin{array}{l}\text { December } 2017 \\
\text { Seoul, Korea }\end{array}$ \\
\hline & $\begin{array}{l}\text { "The exaggerated pressure of a win-win idea or mandatory CSR may } \\
\text { make corporations feel tired. Moreover, if it is regulated by law, } \\
\text { companies will regard CSR/CSV as compliance, and will never link } \\
\text { CSV to business opportunity or strategy, because they are mutually } \\
\text { exclusive." } \\
\text { (CEO, Global Competitiveness Empowerment Forum) }\end{array}$ & $\begin{array}{l}\text { March } 2017 \\
\text { Seoul, Korea }\end{array}$ \\
\hline
\end{tabular}




\begin{tabular}{|c|c|c|}
\hline Country & Quotations & Interview date/location \\
\hline \multirow[t]{2}{*}{ India } & $\begin{array}{l}\text { "We approach CSR and CSV differently. We do CSR as an obligation } \\
\text { to follow government law (the } 2013 \text { CSR Act)—it should not be } \\
\text { linked to our business and strategy. We think of CSV in a separate } \\
\text { way, as our business strategy." } \\
\text { (Senior Vice President, International food company, India) }\end{array}$ & $\begin{array}{l}\text { July } 2017 \\
\text { New Delhi, India }\end{array}$ \\
\hline & $\begin{array}{l}\text { "... the opportunity side for this is the collaborative model for } \\
\text { sustainable development-how businesses and NGOs now work } \\
\text { together with the government towards achievement of national } \\
\text { goals as well as UN SDGs." } \\
\text { (Director of global NGO, India) }\end{array}$ & $\begin{array}{l}\text { July } 2017 \\
\text { New Delhi, India }\end{array}$ \\
\hline
\end{tabular}

\section{References}

Alsop, R. (2007). Why teaching of ethics continues to be lacking. The Wall Street Journal, 19 June. Retrieved from https://www.wsj.com/articles/SB118222013621140038.

Amann, B., Jaussaud, J., \& Martinez, I. (2012). Corporate social responsibility in Japan: Family and nonfamily business differences and determinants. Asian Business \& Management, 11(3), 329-345.

Barr, M. D. (2000). Lee Kuan Yew and the "Asian Values" debate. Asian Studies Review, 24(3), 309-334.

Bettis, R. A., Gambardella, A., Helfat, C., \& Mitchell, W. (2015). Qualitative empirical research in strategic management. Strategic Management Journal, 36(5), 637-639.

Carroll, A. N., \& Bucholtz, A. K. (2003). Business and society: Ethics and stakeholder management. Mason: Thomson Learning.

Carroll, R., Primo, D., \& Richter, B. K. (2016). Using item response theory to improve measurement in strategic management research: An application to corporate social responsibility. Strategic Management Journal, 37(1), 66-85.

Chan, R. Y. K., Cheng, L. T. W., \& Szeto, R. W. F. (2002). The dynamics of guanxi and ethics for Chinese executives. Journal of Business Ethics, 41(4), 327-336.

Chen, Z., Fuller, D. B., \& Zheng, L. (2018). Institutional isomorphism and Chinese private corporate philanthropy: state coercion, corruption, and other institutional effects. Asian Business \& Management, 17(2), 83-111.

Cheung, Y. L., Tan, W., Ahn, H.-J., \& Zhang, Z. (2010). Does corporate social responsibility matter in Asian emerging markets? Journal of Business Ethics, 92(3), 401-413.

Chikudate, N. (2009). Collective hyperopia and dualistic natures of corporate social responsibility in Japanese companies. Asian Business \& Management, 8(2), 169-184.

Cho, S., \& Hong, Y. (2009). Netizens' evaluations of corporate social responsibility: Content analysis of CSR news stories and online readers' comments. Public Relations Review, 35, 147-149.

Choi, T. H. (2012). Do ethical companies have lower implied cost of equity capital? Evidence from the Korean stock market. Asian Business \& Management, 11(2), 219-246.

Choi, D. W., Kim, K. B., \& Lee, S. M. (2015). Impact of the creating shared value's motivation and performance on the stakeholders. Journal of Corporation Management, 22(2), 153-174.

Choi, T. H., \& Nakano, C. (2008). The evolution of business ethics in Japan and Korea over the last decade. Human Systems Management, 27, 183-199.

Choi, Y.-H., Souiden, N., \& Skandrani, H. (2012). The differential impact of trust types on inter-firm relationships: Some empirical evidences from the Japanese eyeglass industry. Asian Business \& Management, 11(5), 541-562.

Chun, R. (2017). Samsung, shame, and corporate atonement. Harvard Business Review, 95(May), 2-5.

Chung, C. Y., Cho, S. J., \& Ryu, D. (2019). Institutional blockholders and corporate social responsibility. Asian Business \& Management. https://doi.org/10.1057/s41291-018-00056-w.

Clark, L. A., \& Robert, S. J. (2010). Employer's use of social networking sites: A socially irresponsible practice. Journal of Business Ethics, 95(4), 507-525. 
Crane, A., Palazzo, G., Spence, L. J., \& Matten, D. (2014). Contesting the value of "creating shared value". California Management Review, 56(2), 130-153.

de los Reyes, G., Scholz, M., \& Smith, N. C. (2017). Beyond the "win-win": Creating shared value requires ethical frameworks. California Management Review, 59(2), 142-167.

Dembek, K., Singh, P., \& Bhakoo, V. (2016). Literature review of shared value: a theoretical concept or a management buzzword? Journal of Business Ethics, 137(2), 231-267.

Disparte, D. (2016). Simple ethics rules for better risk management. Harvard Business Review, 94(November), 2-4.

Dowling, G., \& Moran, P. (2012). Corporate reputations: Built in or bolted on? California Management Review, 54(2), 25-42.

Dzever, S., \& Gupta, B. (2012). Business process outsourcing industry in India: Additional benefits of a CSR approach. Asian Business \& Management, 11(3), 273-289.

Eweje, G., \& Sakaki, M. (2015). CSR in Japanese Companies: Perspectives from managers. Business Strategy and the Environment, 24, 678-687.

Friedman, M. (1970). The social responsibility of business is to increase its profits. The New York Times Magazine. 13 September.

Fukukawa, K., \& Moon, J. (2004). A Japanese model of corporate social responsibility? A study of website reporting. The Journal of Corporate Citizenship, 16, 45-59.

Hanlon, G., \& Fleming, P. P. (2009). Updating the critical perspective on corporate social responsibility. Sociology Compass, 3(6), 937-948.

Hart, S. L. (1995). A natural-resource-based view of the firm. The Academy of Management Review, 20(4), 986-1014.

Hartman, L. P., \& Werhane, P. H. (2013). Proposition: Shared value as an incomplete mental model. Business Ethics Journal Review, 1(6), 36-43.

House, R. J., Hanges, P. J., Javidan, M., Dorfman, P. W., \& Gupta, V. (Eds.). (2004). Culture, leadership, and organizations: The GLOBE study of 62 societies. Thousand Oaks, CA: Sage.

Il, W. T. S., Newenham-Kahindi, A., \& Oh, C. H. (2016). Understanding the words of relationships": Language as an essential tool to manage CSR in communities of place. Journal of International Business Studies, 46(2), 153-179.

Illia, L., Zyglidopoulos, S. C., Romenti, S., Rodríguez-Cánovas, B., \& del Valle Brena, A. G. (2013). Communicating corporate social responsibility to a cynical public. MIT Sloan Management Review, 54(3), 15-18.

Inoguchi, T., \& Newman, E. (1997). Introduction: 'Asian values' and democracy in Asia. Asian Values and Democracy in Asia, 27, 862-891.

Jackson, G., \& Moerke, A. (2005). Continuity and change in Corporate Governance: Comparing Germany and Japan. Corporate Governance an International Review, 13(3), 351-361.

Jarzabkowski, P., \& Whittington, R. (2008). Directions for a troubled discipline: Strategy research, teaching, and practice-Introduction to the dialog. Journal of Management Inquiry, 17(4), 266-268.

Jeong, S. W., Jin, B., Chung, J.-E., \& Yang, H. (2017). Network evolution and cultivation patterns during the internationalization process: Case analyses from Korean SMEs. Asian Business \& Management, 16(4-5), 323-351.

Johnson, G., Langley, A., Melin, L., \& Whittington, R. (2007). Strategy as practice. Cambridge: Cambridge University Press.

Jones, T. M. (1983). An integrating framework for research in business and society: A step towards the elusive paradigm? Academy of Management Review, 8(4), 559-564.

Jose, P. D. (2016). Business and society: Creating shared value: In conversation with N. R. Narayana Murthy, Founder, Infosys. IIMB Management Review, 28(1), 43-51.

Kaku, R. (1997). The path of Kyosei. Harvard Business Review, 75, 55-64.

Kannabiran, G. (2009). Sustainable stakeholder engagement through innovative supply chain strategy: An exploratory study of an Indian organization. Asian Business \& Management, 8(2), 205-223.

Katzenstein, P. J., \& Shiraishi, T. (1997). Network power: Japan and Asia. Ithaca: Cornell University Press.

Kim, R. C. (2018). Can creating shared value (CSV) and the United Nations Sustainable Development Goals (UN SDGs) collaborate for a better world? Insights from East Asia. Sustainability, 10(11), 4128. https://doi.org/10.3390/su10114128.

Kim, R. C., Amaeshi, K., Harris, S., \& Suh, C. (2013). CSR and the national institutional context: The case of South Korea. Journal of Business Research, 66(12), 2581-2591. 
Kim, J. D., An, H.-T., Myung, J. K., \& Bae, S. M. (2016). Assessing CSV as a successful strategic CSR. Korean Business Review, 20(1), 291-318.

Kim, R. C., \& Moon, J. (2015). Dynamics of corporate social responsibility in Asia: Knowledge and norms. Asian Business and Management, 14(5), 1-34.

Kim, R. C., Yoo, I., \& Uddin, H. (2018). The Korean Air nut rage scandal: Domestic versus international responses to a viral incident. Business Horizons, 61(4), 533-544.

Kroeger, A., \& Weber, C. (2015). Developing a conceptual framework for comparing social value creation. Academy of Management Review, 39(4), 43-70.

Lee, D., Moon, J., Cho, J., Kang, H.-G., \& Jeong, J. (2014). From corporate social responsibility to creating shared value in the Korean bakery industry: A case study of the SPC Group. Asia Pacific Business Review, 20(3), 461-483.

Lorenzo-Molo, M. C. F. (2009). Why corporate social responsibility (CSR) remains a myth: The case of the Philippines. Asian Business \& Management, 8(2), 149-168.

Martin, R. L. (2002). The virtue matrix: Calculating the return on corporate responsibility. Harvard Business Review, 80(3), 68-75.

Matten, D., \& Moon, J. (2008). 'Implicit' and 'Explicit' CSR: A conceptual framework for a comparative understanding of corporate social responsibility. Academy of Management Review, 33, 404-424.

McGinn, D., \& Zoltners, A. (2015). Getting beyond "show me the money": An interview with Andris Zoltners. Harvard Business Review, 93(4), 77-81.

Mizuho. (2017). Mizuho Financial Group Integrated Report 2017. Retrieved from https://www.mizuh o-fg.com/investors/financial/annual/data1703/pdf/data1703_all.pdf.

Moskalev, S., \& Park, S. C. (2010). South Korean chaebols and value-based management. Journal of Business Ethics, 92(1), 49-62.

North, D. C. (1990). Institutions, institutional change and economic performance. Cambridge: Cambridge University Press.

Paine, L. S. (2003). Value shift: Why companies must merge social and financial imperatives to achieve superior performance. New York: McGraw-Hill.

Paramanand, B. (2013). Michael porter is a pirate-Stuart Hart. ManagementNext, 10(1), 6-7.

Pfitzer, M., Bockstette, V., \& Stamp, M. (2013). Innovating for shared value. Harvard Business Review, 91(9), 101-107.

Porter, M., \& Kramer, M. R. (2011). Creating shared value. Harvard Business Review, 89(1/2), 62-77.

Rangan, K., Chase, L., \& Karim, S. (2015). The truth about CSR: Most of these programs aren't strategic-And that's OK. Harvard Business Review, 93, 42-49.

Roberts, J. (2003). The manufacture of corporate social responsibility: Constructing corporate sensitivity. Organization, 10(2), 249-265.

Ryu, D., Ryu, D., \& Hwang, J. H. (2017). Corporate governance, product-market competition, and stock returns: Evidence from the Korean market. Asian Business \& Management, 16(1-2), 50-91.

Sagar, P., \& Singla, A. (2004). Trust and corporate social responsibility: Lessons from India. Journal of Communication Management, 8(3), 282-290.

Saito, A. (2008). Bushido. In R. W. Kolb (Ed.), Encyclopedia of business ethics and society (pp. 208210). Los Angeles, CA: Sage.

Sandel, M. (2013). What money can't buy: The moral limits of markets. Fsgbooks.com.

SK Telecom. (2014). SK Telecom Annual Report 2013: Partner for new possibility. Retrieved from https ://www.sktelecom.com/img/kor/persist_report/20140806/SUSTAIN_REPORT_2013_ENG.pdf.

Smith, C. (1994). The new corporate philanthropy. Harvard Business Review, 72(3), 105-115.

Strand, R., \& Freeman, R. E. (2015). Scandinavian cooperative advantage: The theory and practice of stakeholder engagement in Scandinavia. Journal of Business Ethics, 127(1), 65-85.

Suzuki, K., Tanimoto, K., \& Kokko, A. (2010). Does foreign investment matter? Effects of foreign investment on the institutionalisation of corporate social responsibility by Japanese firms. Asian Business \& Management, 9(3), 379-400.

Swanson, D. L. (1999). Toward an integrative theory of business and society: A research strategy for corporate social performance. The Academy of Management Review, 24(3), 506-521.

Takashi, N. (2015). Creating shared value for management innovation. Tokyo: Toyo Keizai.

Teng, M.-J. (2011). The effects of an environmental management system on intangible assets and corporate value: Evidence from Taiwan's manufacturing firms. Asian Business \& Management, 10(3), $381-404$.

The Federation of Korean Industries (2014). FKI Issue Paper: Major enterprises and foundations social contribution white paper. FIP-2014-0007 (2014. 11). 
Tokoro, N. (2007). Stakeholders and corporate social responsibility (CSR): A new perspective on the structure of relationships. Asian Business \& Management, 6(2), 143-162.

Vaara, E., \& Whittington, R. (2012). Strategy-as-practice: Taking social practices seriously. The Academy of Management Annals, 6(1), 285-336.

Valax, M. (2012). Beyond McDonald's CSR in China: Corporation perspective and report from case study research on a damaged employment reputation. Asian Business and Management, 11(3), $347-366$.

Vogel, D. (2005). The market for virtue: The potential and limits of corporate social responsibility. Washington: Brookings Institution Press.

Wang, L., \& Juslin, H. (2009). The impact of Chinese culture on corporate social responsibility: The harmony approach. Journal of Business Ethics, 88(3), 433-451.

Witt, M. A., \& Redding, G. (2012). The spirits of Corporate Social Responsibility: senior executive perceptions of the role of the firm in society in Germany, Hong Kong, Japan, South Korea and the USA. Socio-Economic Review, 10, 09-134.

Witt, M. A., \& Redding, G. (2014). The Oxford Handbook of Asian business systems. Oxford: Oxford University Press.

Wong, L. (2009). Corporate social responsibility in China: Between the market and the search for a sustainable growth development. Asian Business \& Management, 8(2), 129-148.

Wu, J., \& Wokutch, R. E. (2015). Confucian stakeholder theory: An exploration. Business and Society Review, 120(1), 1-21.

Zenger, T. (2016). Beyond competitive advantage: How to solve the puzzle of sustaining growth while creating value. Boston: Harvard Business Review Press.

Publisher's Note Springer Nature remains neutral with regard to jurisdictional claims in published maps and institutional affiliations.

Rebecca Chunghee Kim is Professor at the College of International Management \& Graduate School of Management, Ritsumeikan Asia Pacific University. Her research interests include Asian CSR and CSV, the Varieties of Capitalism, missing-employee issues in CSR discussions, institutional dynamics of CSRHRM relationships, and CSR comparative study between Asia and the West. She has published in journals such as Journal of Business Research, Journal of Business Ethics, European Journal of International Management and Business Horizons.

Akira Saito has been a board member of Japan Society for Business Ethics Study (JABES) from 2005 while a member of Society for Business Ethics (SBE). He has worked at Sumitomo Corporation for 31 years since 1967. After he has retired from Sumitomo Corporation, he has taught at the Graduate School of Policy Studies at Chuo University as a Visiting Professor, on Corporate Philosophy, Business Ethics, CSR and Corporate Governance. His articles were published including SAGE Encyclopedia of Business Ethics and Society, and others.

V. Mohan Avvari is Associate Professor and Director of Research at the Nottingham University Business School (NUBS) in Malaysia. His research interests are in strategy (sustainability/responsible business) and innovation. He is particularly interested in innovation systems - linkages business organisations develop with other organisations for innovation and sustainable development/CSR. He is on the editorial panel for research journals like, Asian Journal of Technology Innovation, Asian Journal of Innovation and Policy, World Technopolis Review and Journal of Open Innovation TMC. 